\title{
Social Scientists and Related Workers
}

National Cancer Institute

\section{Source}

National Cancer Institute. Social Scientists and Related Workers. NCI Thesaurus. Code C122509.

The group of professions that include economists, marketing research analysts, survey researchers, clinical, counseling, and school psycholog ists, industrial-organizational psychologists, sociologists, urban and regional planners, anthropologists and archeologists, geographers, historians, and political scientists. 